\title{
SEISMIC PERFORMANCE OF STRUCTURE WITH FIXED BASE, BASE ISOLATED STRUCTURE AND STRUCTURE WITH VISCOUS DAMPER
}

\author{
Dhananjay A. Chikhalekar', M. M. Murudi \\ ${ }^{1}$ Post Graduate Student, Department of Structural Engineering, Sardar Patel College of Engineering, Mumbai, India \\ ${ }^{2}$ Professor, Department of Structural Engineering, Sardar Patel College of Engineering, Mumbai, India
}

\begin{abstract}
Earthquakes can create serious damage to structures. The structures already built are vulnerable to future earthquakes. The damage to structures causes deaths, injuries, economic loss, and loss of functions. Damage to the structure causes due to ground acceleration. This can be minimizing by increasing strength of the structure. Sometimes it is not possible to increase the strength of the structure indefinitely. So it should be tried to increase the capacity of structure using seismic improvement techniques. In this study, there are three different types of G+10 structures with fixed base, structure with viscous damper and structure with high damping rubber bearing are considered. These structures are modeled using finite element software SAP2000v16. These structures have same plan area and are assumed to be situated in seismic zone IV and having medium soil condition. The analysis of these structures is done by performance based pushover analysis method and response spectrum method. The pushover analysis method is used to find out the performance point and capacity of structure. High damping rubber bearing isolators (HDRB) and viscous damper $(V D)$ are use for seismic improvement of $R C$ structure. The procedure of analysis adopted for fixed base structure is same repeated for structure with viscous damper (VD) and base isolated (HDRB) structure. So it will help in comparative parametric study. The results of analysis are compared in terms of storey displacements, modal time period, storey acceleration, performance point, storey drift. The comparative study shows that storey displacement, storey acceleration, storey drift is reduced substantially for structure with high damping rubber bearing (base isolated structure).
\end{abstract}

Key Words: Base isolated structure, Pushover analysis method, Response spectrum method, Viscous damper, High damping rubber bearing, SAP2000v16 etc.

\section{INTRODUCTION}

Earthquake occurrence is still remaining unpredictable to the engineers. Our Indian subcontinent has experienced some of the most severe earthquakes in the world and researches have shown that the tectonic activities are still continuing which may result into severe earthquakes in future. Recently, Nepal earthquake (April 2015) killed and injured lot of people. Many residential and public structures have collapsed in this earthquake. Therefore it is essential to protect existing structures from future earthquakes. The existing building found inadequate for resisting future probable earthquake. The old method of providing earthquake resistance to a structure is by increasing its strength, stiffness and capacity. Earthquake resistant design of reinforced concrete structure is a continuing area of research since earthquake engineering has started not only in India but also in other countries. The seismic improvement also may helpful to withstand during sever earthquakes. The basic need to the protect structure from earthquake ground motions and keep it to minimum hazard level. Damping in the structure always reduces acceleration and displacement in the structure. The base isolation techniques and energy dissipation techniques such as a damper reduces response of structure hence there is a necessity to investigate the effect of base isolators and dampers on the response of structure. Seismic isolation separates the superstructure from substructure and it prevents transmission of ground motion from foundations to superstructure. The system which separates superstructure from substructure is known as isolators. Isolated structure has fundamental frequency is much lower than that of fundamental frequency of fixed base structure and predominant frequencies of a typical earthquake. Energy dissipation dampers are of different types i.e. viscous damper, friction damper, tunned mass damper, Visco-elastic damper etc. Base isolator and dampers substantially reduces response of structure.

\subsection{PRINCIPLE OF BASE ISOLATION}

The basic principle of base isolation is to modify the response of the structure so that the ground can move below the structure without transmitting these motions into the superstructure. A structure that is perfectly rigid will have a zero period. Base isolators are needed to be placed between superstructure and foundation. When the ground moves, the acceleration induced in the structure will be equal to the ground acceleration and there will be zero relative displacement between the superstructure and the ground. Both structure and ground move with the same amount. 
Perfectly flexible structure will have an infinite period. For this type of structure, when the ground beneath the structure moves, there will be zero acceleration induced in the structure and the relative displacement between the structure and ground will be equal to the ground displacement [1]. The structure will not move, the ground will move. In buildings, High damping rubber bearing isolator protects the structural components from earthquake loads in two ways: (i) by deflecting seismic energy and (ii) by absorbing seismic energy. The seismic energy is deflected by allowing base of the structure to displace in lateral directions. This will results into increasing the natural time period of the structure. The structure which having longer natural time period attracts less seismic force, the base isolation system deflects the seismic energy. There are different types of base isolator's i.e. laminated rubber bearing, Lead rubber bearing, High damping rubber bearing and Friction pendulum system. Fig-1 shows behavior of structure with and without base isolated structure.

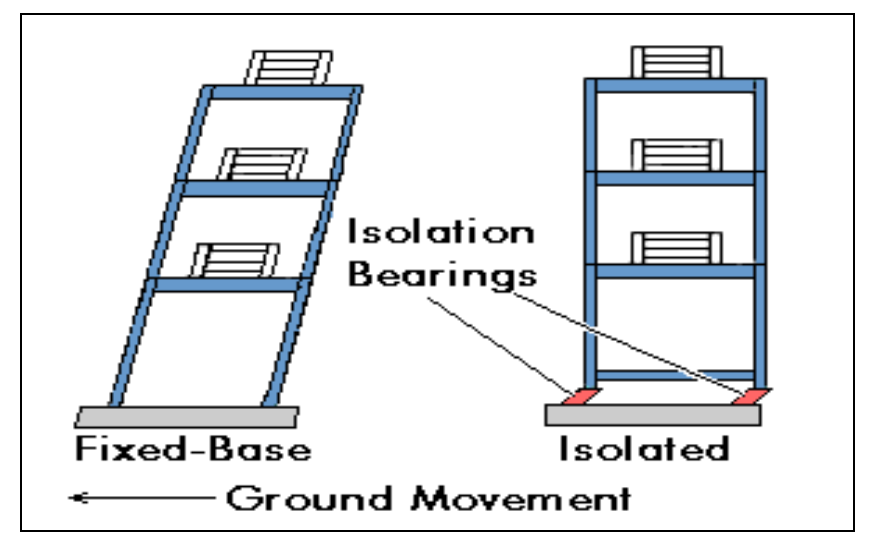

Fig -1: Base isolated structure

\subsection{HIGH DAMPING RUBBER BEARING}

High damping rubber bearing is one of the type of elastomeric bearing. In this type of isolator, elastomer is used. This elastomer is generally made up with either natural or synthetic rubber. This provides significant amount of damping ranges from $8 \%$ to $15 \%$ of critical [1].

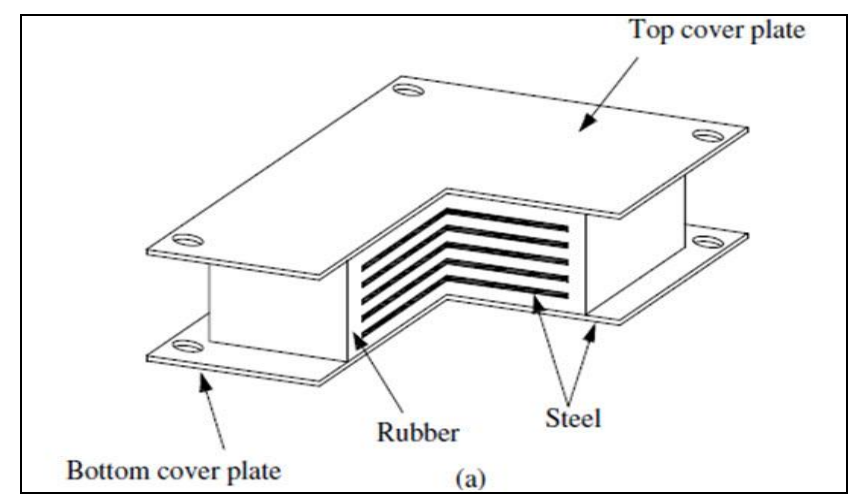

Fig -2: High damping rubber bearing isolator

Usual rubber compound provides around 2\% damping. Extra amount of damping is produced by modifying the compounding of the rubber and altering the cross link density of the molecules to provide a hysteresis curve in the rubber. Damping provided by isolator is hysteretic in nature which is displacement dependent. For most high damping rubber compounds, viscous component of damping is velocity dependent which remains relatively small about $2 \%$ to $5 \%$ of critical [1]. Fig -2 shows high damping rubber bearing isolator.

\subsection{VISCOUS DAMPER}

Fluid viscous dampers have been incorporated into many civil engineering structures [12]. When the fluid viscous damper is subjected to external loads, piston rod with piston will make reciprocating motion in the cylinder to force the damping medium move back and forth between the two cavities separated by the piston [2].

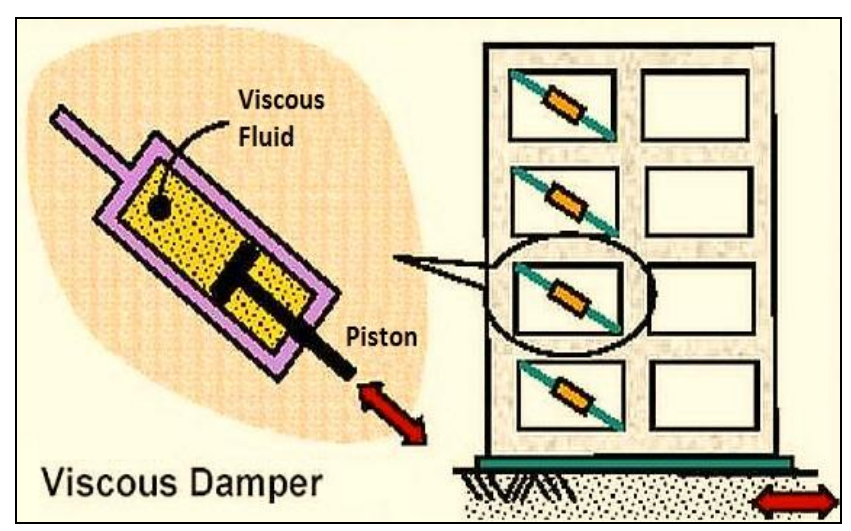

Fig -3: Viscous damper structure

Viscous dampers which utilize the viscous properties of fluids have been developed and used in structural applications. Viscous dampers are use to dissipate or absorb the energy of earthquake induced motion. This will results in preventing structural damage to the structural elements. Stress reduction in the structural elements and greatly enhanced damping, lowers both stress and deflection throughout the structure. Fig -3 shows the structure with viscous damper.

\subsection{PUSHOVER ANALYSIS}

Pushover analysis method is a nonlinear static analysis method. It includes capacity spectrum method. Capacity spectrum method includes capacity curve and demand curve. The intersection of capacity curve and demand curve are required to estimate maximum storey displacement [13]. Capacity and demand are two key elements of performance based pushover analysis procedure. The representation of earthquake ground motion is called as demand. The representation of structure's ability to resist seismic demand is called as capacity. There are two ways to do pushover analysis i.e. forced controlled and displacement controlled. Forced controlled pushover analysis involves applying lateral or horizontal loads in triangular or uniform pattern to the structure, incrementally i.e. pushing the structure in horizontal direction. The plot of total base force and corresponding lateral displacement at each increment gives capacity of structure. In this, structure reaches a limit state. 
In this study, Displacement controlled pushover analysis is done. It is depending on target displacement of structure. Lateral loads are applied to structure in the form of acceleration or displacement to reach the target displacement. Lateral displacement is increased until some structural members yield. The structural model is modified to account for reduced stiffness of yielded structural members. Lateral displacement is again increased until some other structural members yield. This process is continued until the target displacement is reached. The graph of top storey displacement verses base shear gives capacity curve of structure.

\subsection{RESPONSE SPECTRUM METHOD}

Response spectrum method is performed using design spectrum for different site conditions. The maximum response is plotted against the undamped natural period and for various damping values [5]. The results of response spectrum analysis can be presented in form of storey acceleration, storey velocity and storey displacement. Fig -4 shows Response spectrum for different site conditions as per IS 1893:2002 [5].

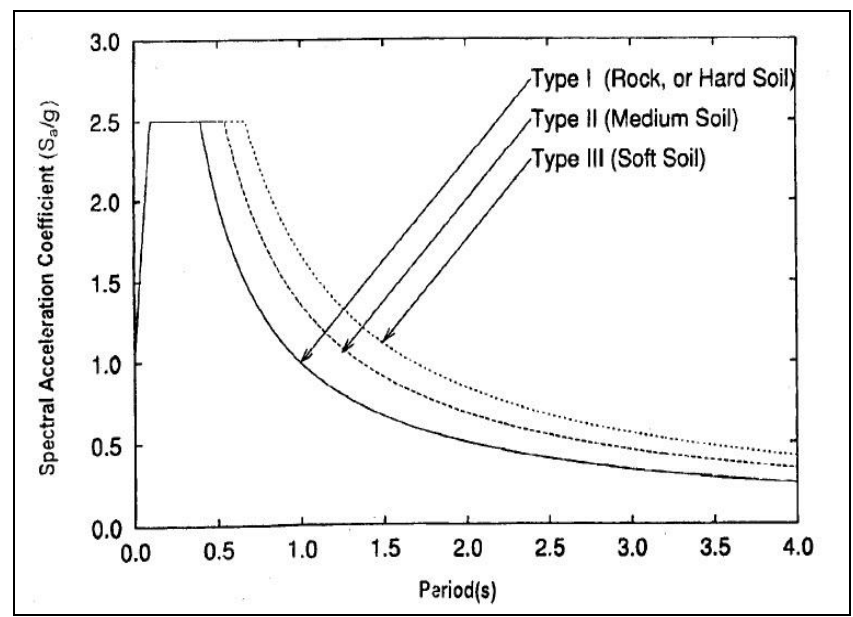

Fig -4: Response spectrum for different site conditions

\section{PROBLEM STATEMENT}

The modeling of G+10 storey structure is done using SAP2000v16. Each type of structure with fixed base, structure with viscous damper and structure with high damping rubber bearing are considered. These structures having same plan area of $182.25 \mathrm{~m}^{2}$. The analysis of these structures is carried out with pushover analysis and response spectrum method. All models of each type structures with fixed base, structure with viscous damper and structure with high damping rubber bearing are assumed to be located in Zone IV have been analyzed by keeping analysis procedure same for all models. The parametric study of seismic performance in terms of storey displacement, storey acceleration, storey velocity, modal time period, performance point, storey drift etc is done.

\subsection{STRUCTURE DETAILS}

$>$ Type of structure: OMRF

$>$ Number of stories: G+10

$>$ Depth of slab: $180 \mathrm{~mm}$

$>$ Unit weight of RCC: $25 \mathrm{KN} / \mathrm{m}^{3}$

$>$ Height of each storey: $3 \mathrm{~m}$

$>$ Plan size: $13.5 \mathrm{~m}$ x $13.5 \mathrm{~m}$

$>$ Unit weight of Masonry: $20 \mathrm{KN} / \mathrm{m}^{3}$

$>$ Member used: Beam: 250mm x 450mm

$>$ Grade of concrete: M30

$>$ Grade of steel: FE415

$>$ Acceptable Hinge Target: Life Safety

\subsection{MODELLING AND ANALYSIS}

The structure is modeled using standard analysis and design tool SAP2000v16 software. Single diagonal tension compression brace with viscous damper with damping force of $700 \mathrm{KN}$ is used [9]. HDRB Isolators are placed at base of the structure. Static and dynamic analysis is carried out by using pushover analysis and response spectrum analysis of these structures with the help of software. Target displacement is considered to be $4 \%$ of height of the structure for the pushover analysis for first iteration. There are two pushover and response spectrum load cases are defined for $\mathrm{X} \& \mathrm{Y}$ direction. And the analysis is carried out. The analysis \& results are demonstrated with the help of figures.

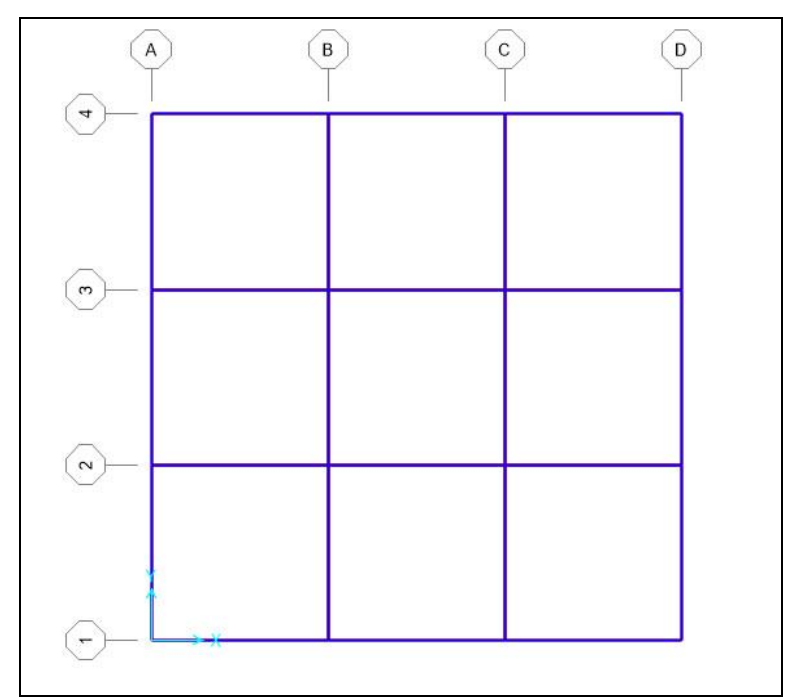

Fig -5: Plan

$\mathrm{G}+10 \mathrm{RC}$ frame structure is taken for study. The plan and elevation of all these structures are shown in Fig -5 and Fig -6, Fig -7, Fig -8 respectively. 


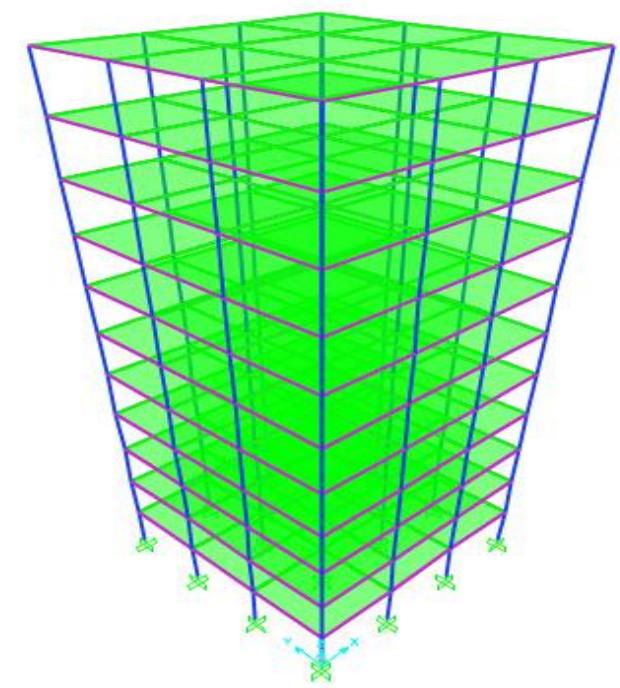

Fig -6: Elevation of fixed base structure

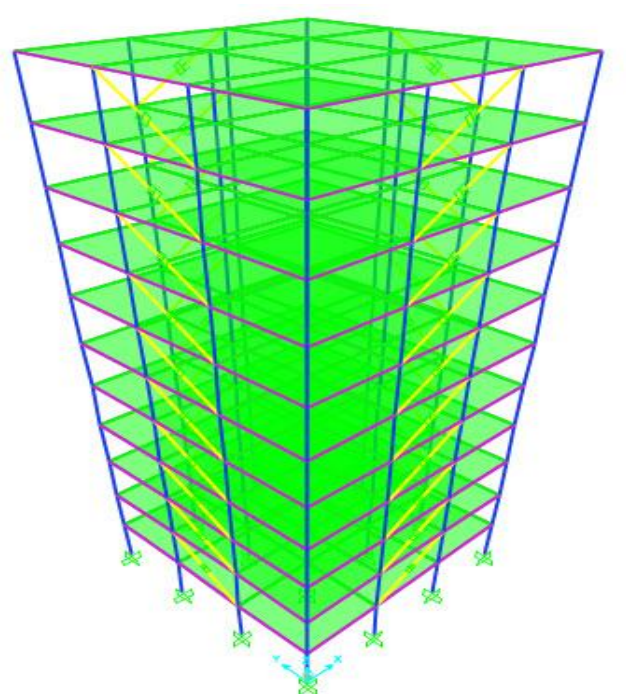

Fig -7: Elevation of structure with viscous damper

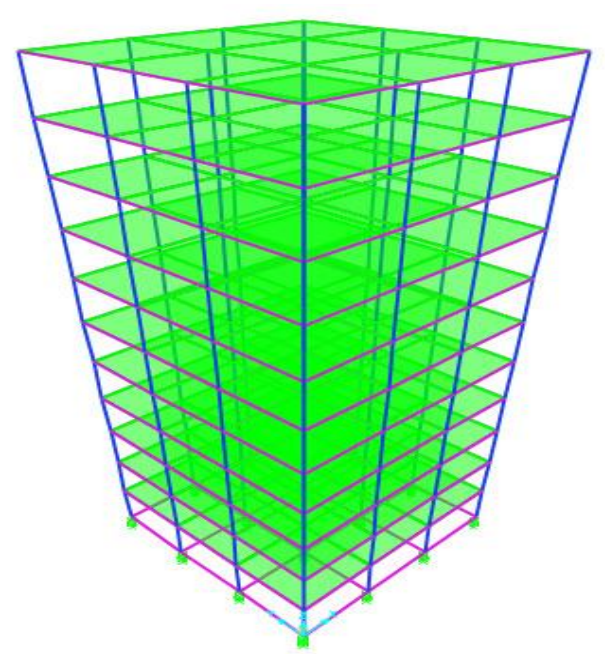

Fig -8: Elevation of base isolated structure

Fig -8, Fig -9, Fig -10 shows the Formation of hinges in fixed base structure, structure with viscous damper and base isolated structure in pushover analysis respectively.

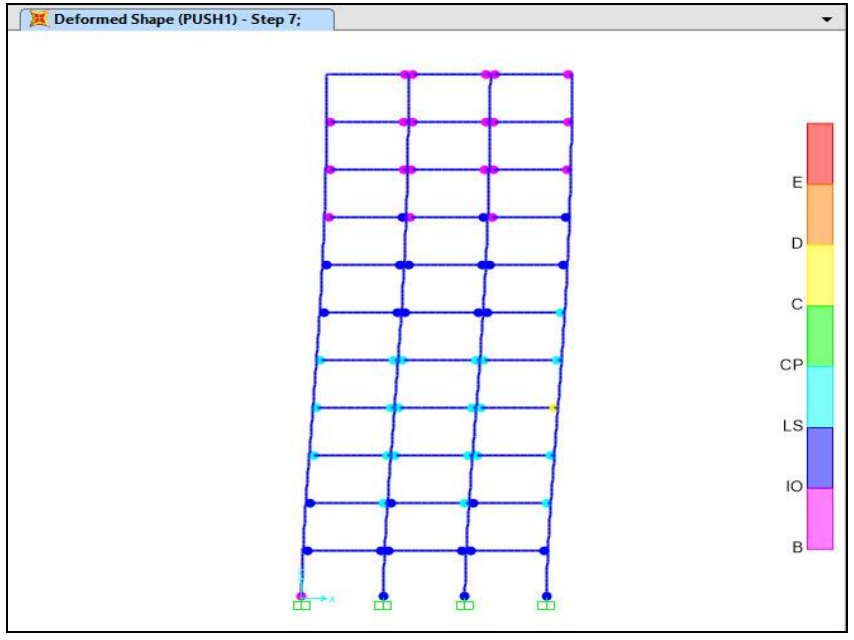

Fig -9: Formation of hinges in fixed base structure

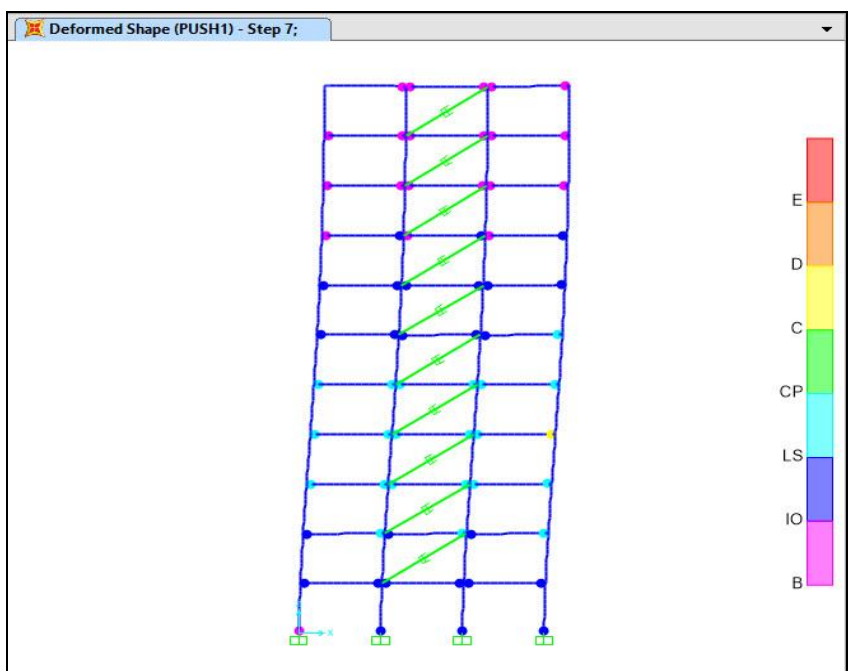

Fig -9: Formation of hinges in viscous damper structure

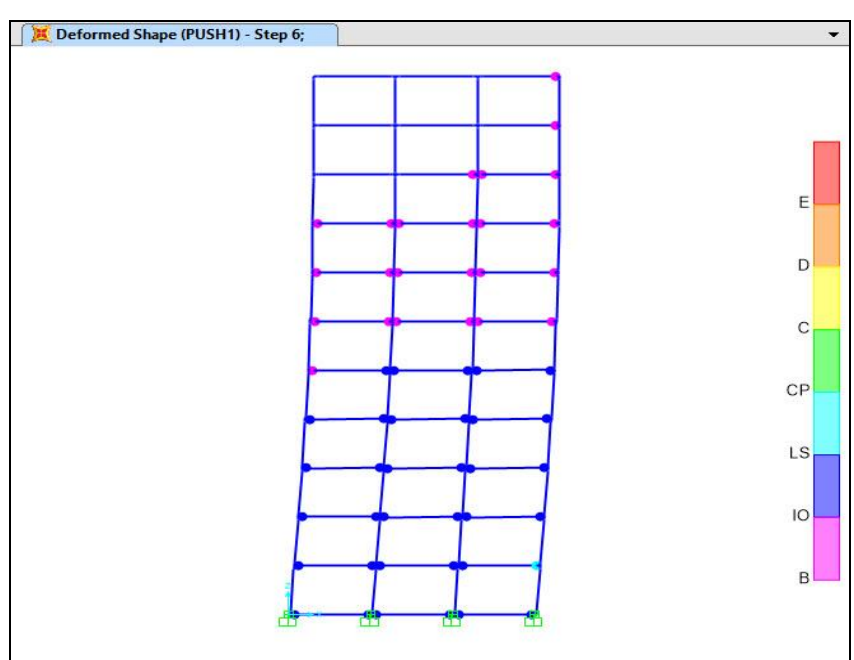

Fig -10: Formation of hinges in base isolated structure

Fig -11, Fig -12, Fig -13 shows the capacity curve of fixed base, structure with viscous damper and base isolated structure in pushover analysis in $\mathrm{X}$ direction respectively. 


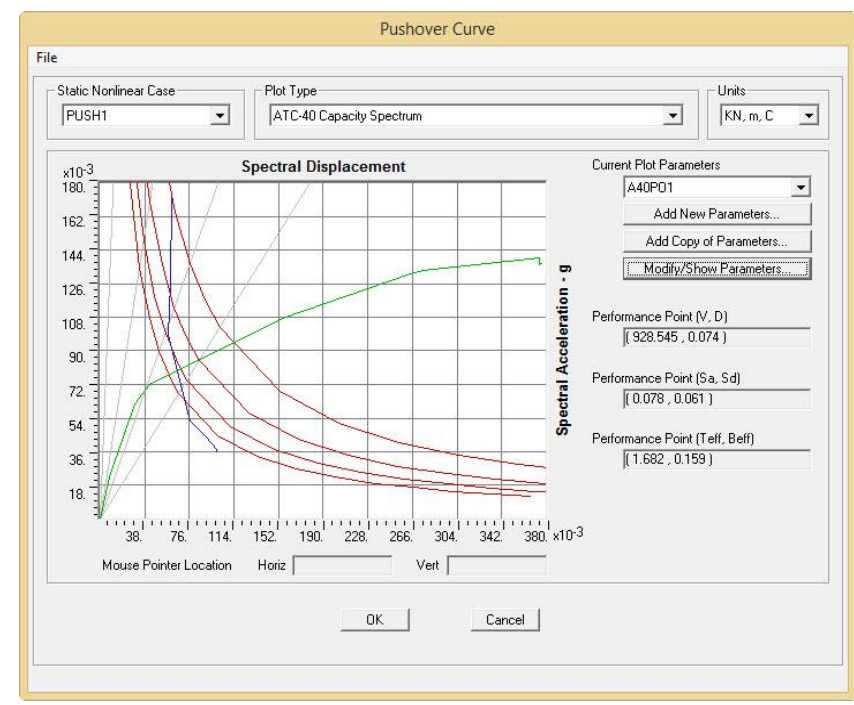

Fig -11: Capacity curve of fixed base structure for pushover in $\mathrm{X}$ direction

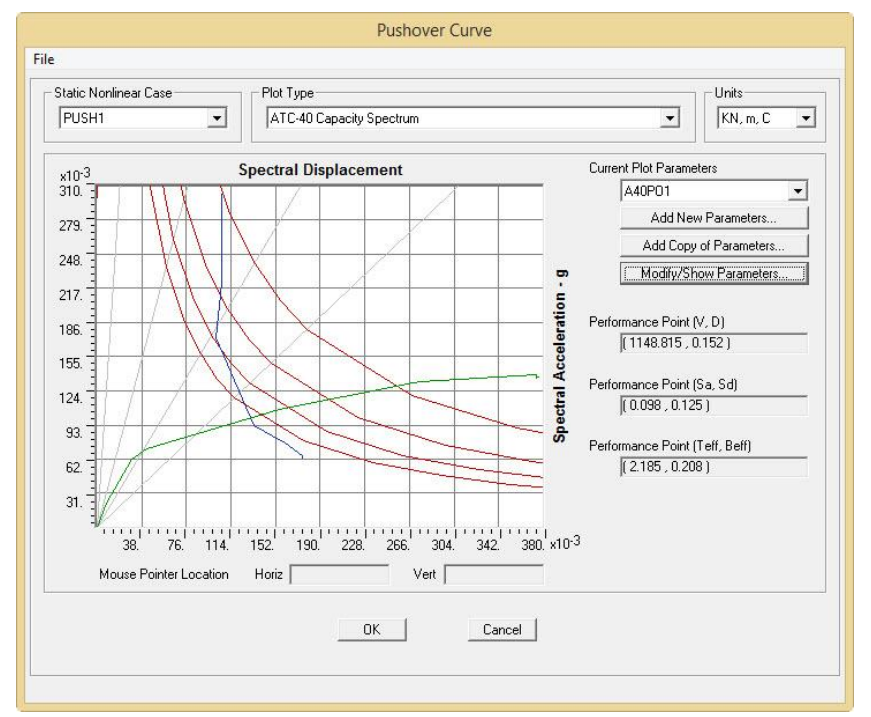

Fig -12: Capacity curve of viscous damper structure for pushover in $\mathrm{X}$ direction

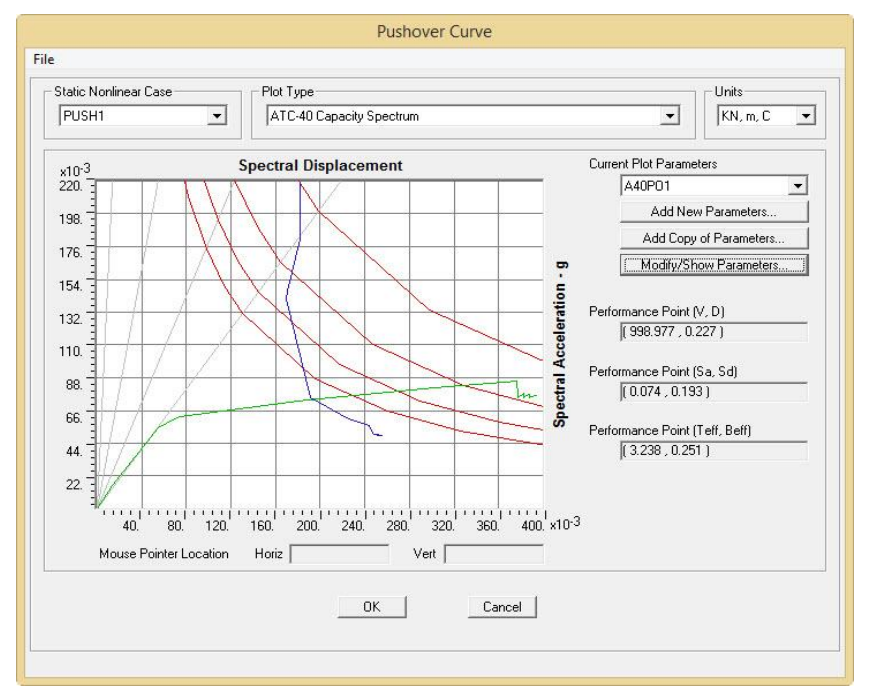

Fig -13: Capacity curve of base isolated structure for pushover in $\mathrm{X}$ direction

\subsection{RESULTS AND DISCUSSION}

\section{Results of pushover analysis}

\section{Performance Point}

It is observed that performance point of fixed base structure, structure with viscous damper (VD), base isolated structure (HDRB) is $74 \mathrm{~mm}, 152 \mathrm{~mm}, 227 \mathrm{~mm}$ and $85 \mathrm{~mm}, 176 \mathrm{~mm}$, $242 \mathrm{~mm}$ in $\mathrm{X} \& \mathrm{Y}$ direction respectively. The performance point of base isolated structure (HDRB) is increased by 2.85 to 3 times and structure with viscous damper (VD) is increased by 2 times to that of fixed base structure. Base isolation prevents the ground motions or accelerations to be transmitted from the foundation into the superstructure. It reduces damage to structural elements in the structure. Due to this, performance point of structure increases. Fig -14 and Fig -15 shows Capacity curve of structures showing performance point in $\mathrm{X}$ and $\mathrm{Y}$ direction respectively.

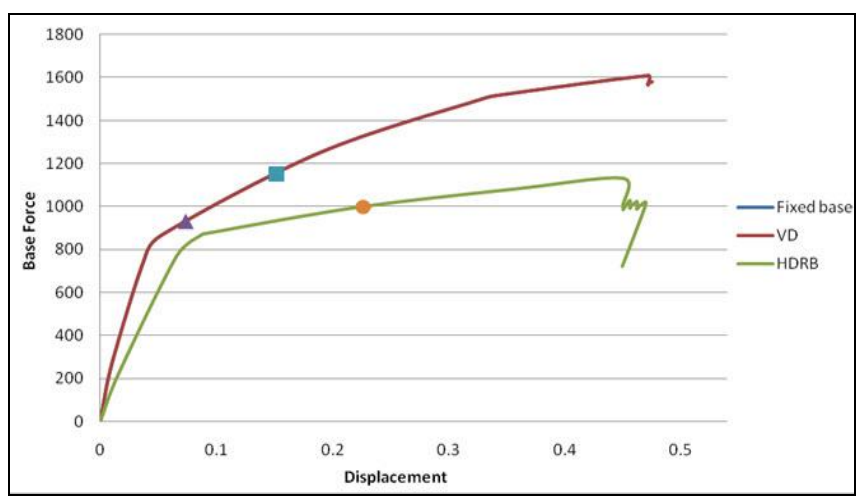

Fig -14: Capacity curve of structures showing performance point

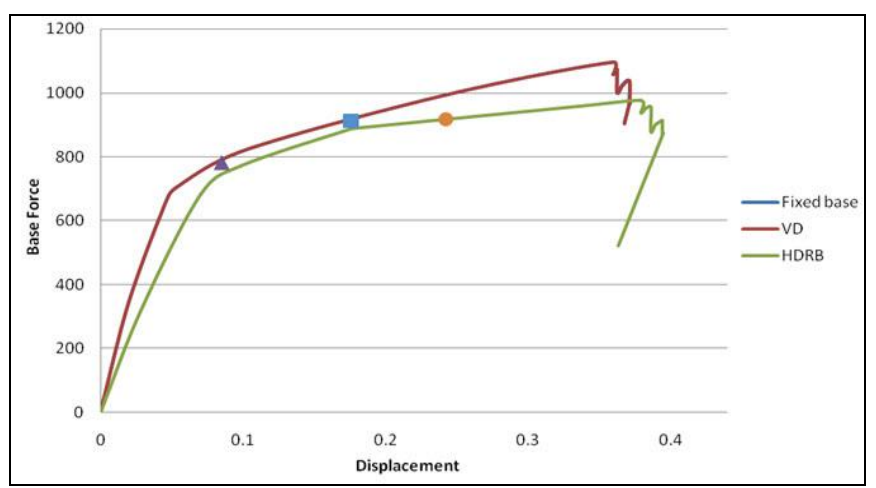

Fig -15: Capacity curve of structures showing performance point

\section{Storey Displacement}

It is observed that storey displacement of structure in pushover analysis of base isolated structure (HDRB) is decreased by $10.16 \%$ \& $3.35 \%$ in $\mathrm{X} \& \mathrm{Y}$ direction respectively. And no much vary in case of structure with viscous damper (VD). High damping rubber bearing isolator increases damping in the structure. Damping decreases storey displacement in base isolated structure. Fig -16 and Fig -17 shows Storey displacement for structures for pushover in $\mathrm{X}$ and $\mathrm{Y}$ direction respectively. 


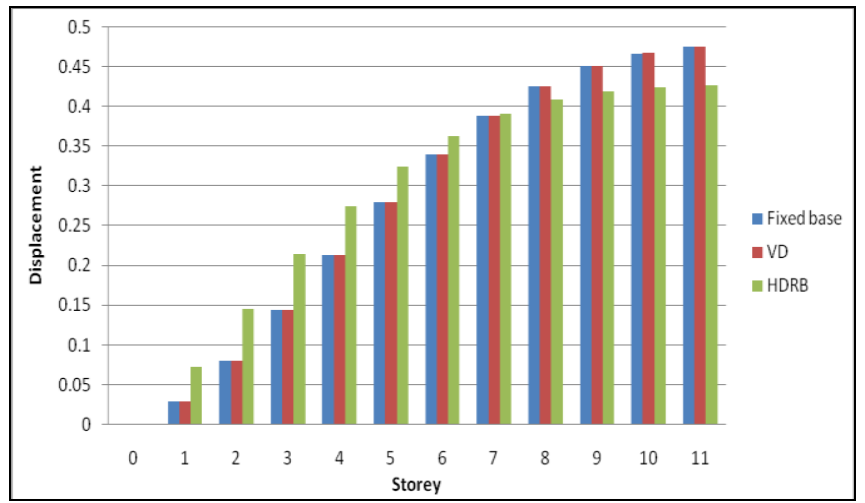

Fig -16: Storey displacement of structures for pushover in $\mathrm{X}$ direction

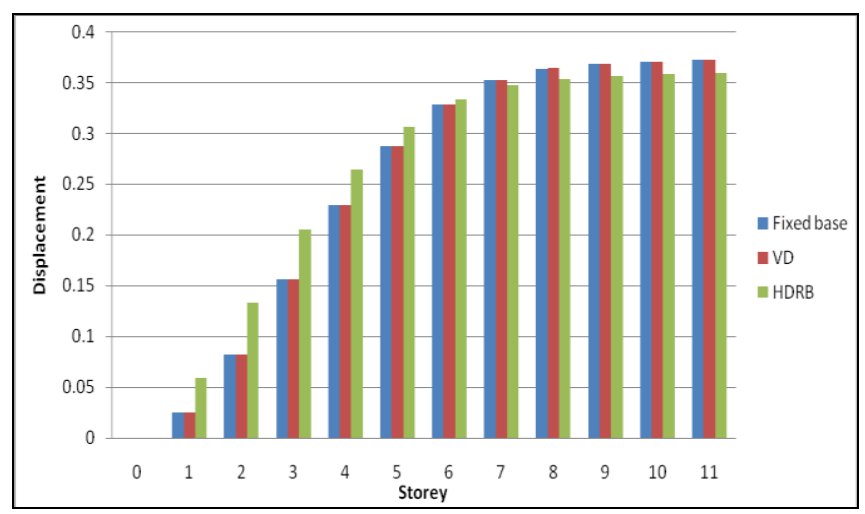

Fig -17: Storey displacement of structures for pushover in $\mathrm{Y}$ direction

\section{Storey Drift}

It is observed that as Storey drift of base isolated structure (HDRB) in pushover analysis is decreased by $25.54 \%$ to $71.59 \%$ \& $8.74 \%$ to $47.90 \%$ in $\mathrm{X} \& \mathrm{Y}$ direction respectively. And no much vary in case of structure with viscous damper (VD). High damping rubber bearing isolator increases damping in the structure. Damping decreases storey displacement in base isolated structure. The base isolated structure has certain displacement at base and superstructure act as rigid body. Hence it has less relative storey drift. The Fig -18 and Fig -19 shows Storey drift of structure for pushover in X \& Y direction respectively.

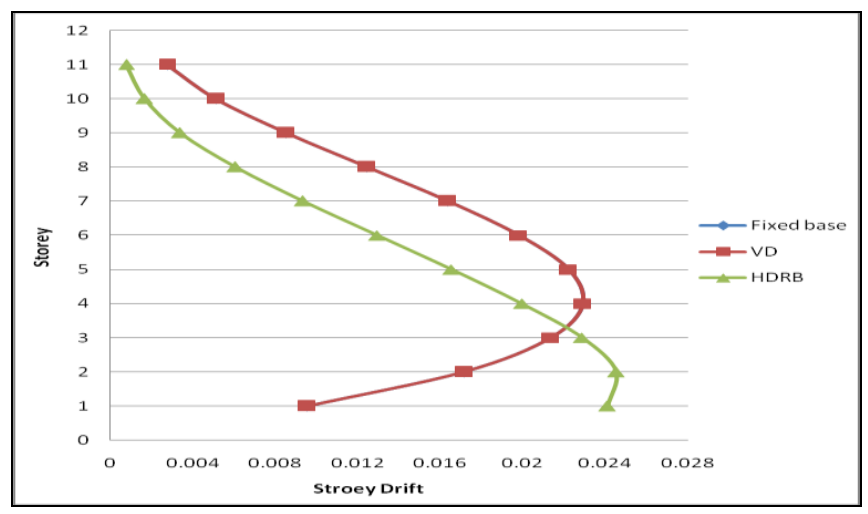

Fig -18: Storey drift of structures for pushover in X direction

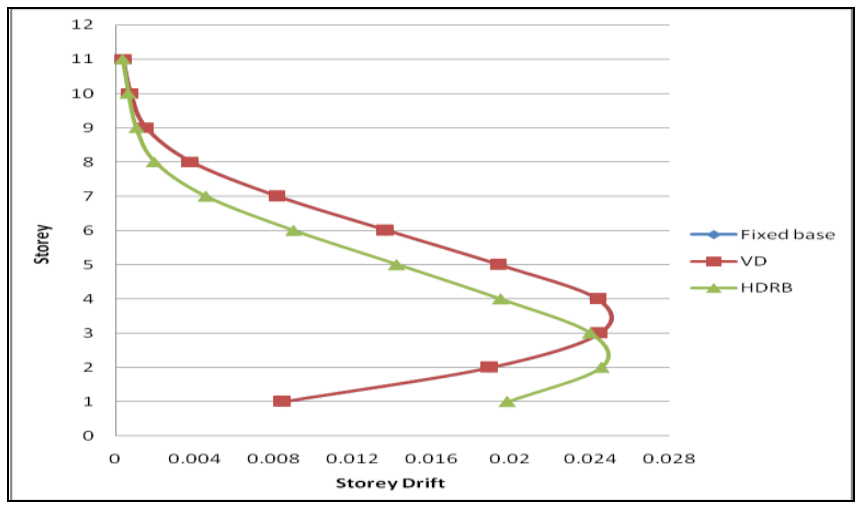

Fig -19: Storey drift of structures for pushover in $\mathrm{Y}$ direction

\section{Time Period}

It is observed that modal time period of base isolated structure (HDRB) is increased by $15.026 \%$ to $35.52 \%$ and in structure with viscous damper (VD), it is decreased by $6.3 \%$ to $14.56 \%$ as compared to fixed base structure. High damping rubber bearing isolator provides flexibility to structure and capable to displaced at certain amount. This displacement of high damping rubber bearing isolator at base of structure results in lengthening the time period of structure. Damping provided by viscous damper results in decrease in time period of structure with viscous damper. Fig -20 shows Modal time period of $\mathrm{G}+10$ structures.

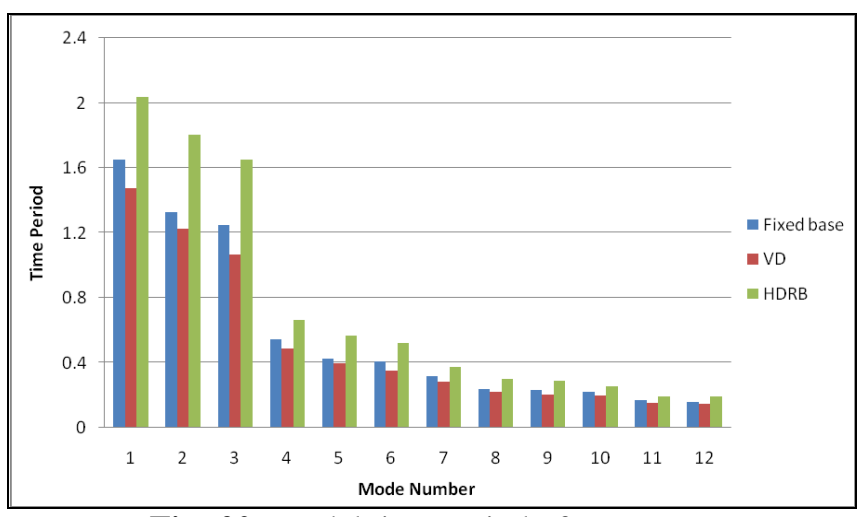

Fig -20: Modal time period of structures

\section{Results of response spectrum analysis}

\section{Storey Acceleration}

It is observed that Storey acceleration in response spectrum analysis of base isolated structure (HDRB) is reduced by $77.21 \%$ to $98.83 \%$ \& $71.92 \%$ to $92.04 \%$ in $\mathrm{X} \& \mathrm{Y}$ direction respectively. And in case of structure with viscous damper (VD), it is reduced by $1.88 \%$ to $7.53 \% \& 2.82 \%$ to $11.03 \%$ in $\mathrm{X} \& \mathrm{Y}$ direction respectively. Both type of isolator and damper reduces storey acceleration compared to fixed base structure. Viscous damper provides damping in the structure. High damping rubber bearing isolator increases damping in the base isolated structure and transfers very less ground motion in the structure above. Damping decreases storey acceleration of the structure. Fig 21 and Fig -22 shows Storey acceleration of structures for $\mathrm{RS}$ analysis in $\mathrm{X} \& \mathrm{Y}$ direction respectively. 


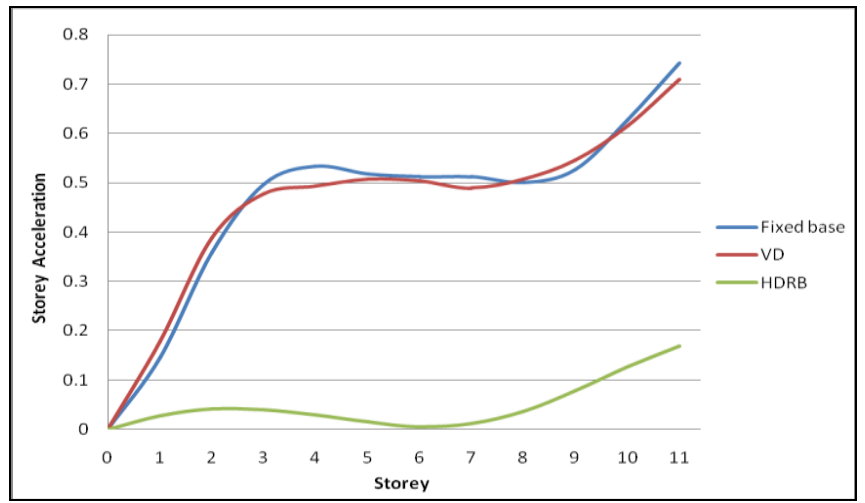

Fig -21: Storey acceleration of structures for RS analysis in $\mathrm{X}$ direction

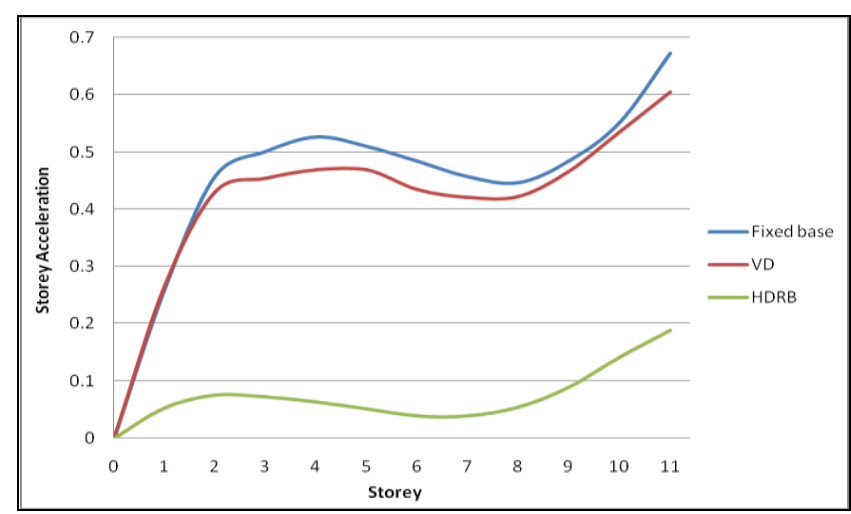

Fig -22: Storey acceleration of structures for RS analysis in Y direction

\section{Storey Displacement}

It is observed that Storey displacement in response spectrum analysis of base isolated structure (HDRB) is decreased by $18.73 \%$ \& $13.82 \%$ in $\mathrm{X} \& \mathrm{Y}$ direction respectively. And in case of structure with viscous damper (VD), it is decreased by $11.42 \% \& 14.6 \%$ in X \& Y direction respectively. Both type of isolator and damper reduces storey displacement compared to fixed base structure. Viscous damper provides damping in the structure. High damping rubber bearing isolator increases damping in base isolated structure. Damping always decreases storey displacement of the structure. Fig -23 and Fig -24 shows Storey acceleration of structures for RS analysis in X \& Y direction respectively.

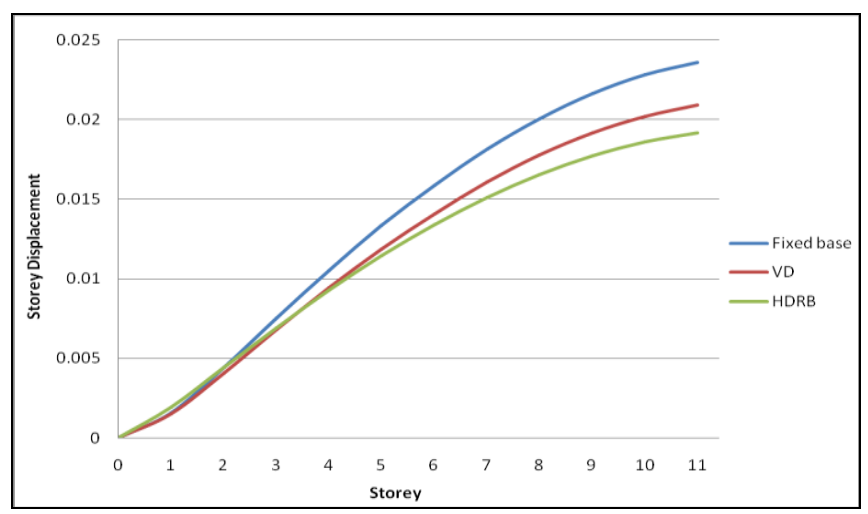

Fig -23: Storey displacement of structures for RS analysis in $\mathrm{X}$ direction

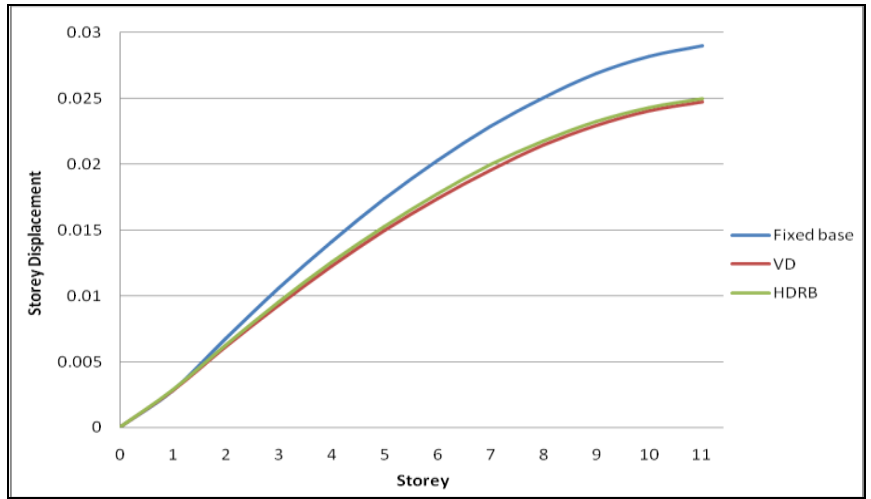

Fig -24: Storey displacement of structures for RS analysis in $\mathrm{Y}$ direction

\section{Storey Drift}

It is observed that Storey drift in response spectrum analysis of base isolated structure (HDRB) is decreased by $25.21 \%$ \& $18.70 \%$ in X \& Y direction respectively. And in case of structure with viscous damper (VD), it is decreased by $11.69 \%$ \& $14.076 \%$ to $17.92 \%$ in $\mathrm{X} \& \mathrm{Y}$ direction respectively. Both type of isolator and damper reduces storey drift compared to fixed base structure. High damping rubber bearing isolator increases damping in the structure. Damping decreases storey displacement in base isolated structure. The base isolated structure has certain displacement at base and superstructure act as rigid body. Hence it has less relative storey drift. Viscous damper provides damping in the structure. This results decrease in storey drift of the structure with viscous damper. Fig -25 and Fig -26 shows Storey drift of structures for RS analysis in X $\& \mathrm{Y}$ direction respectively.

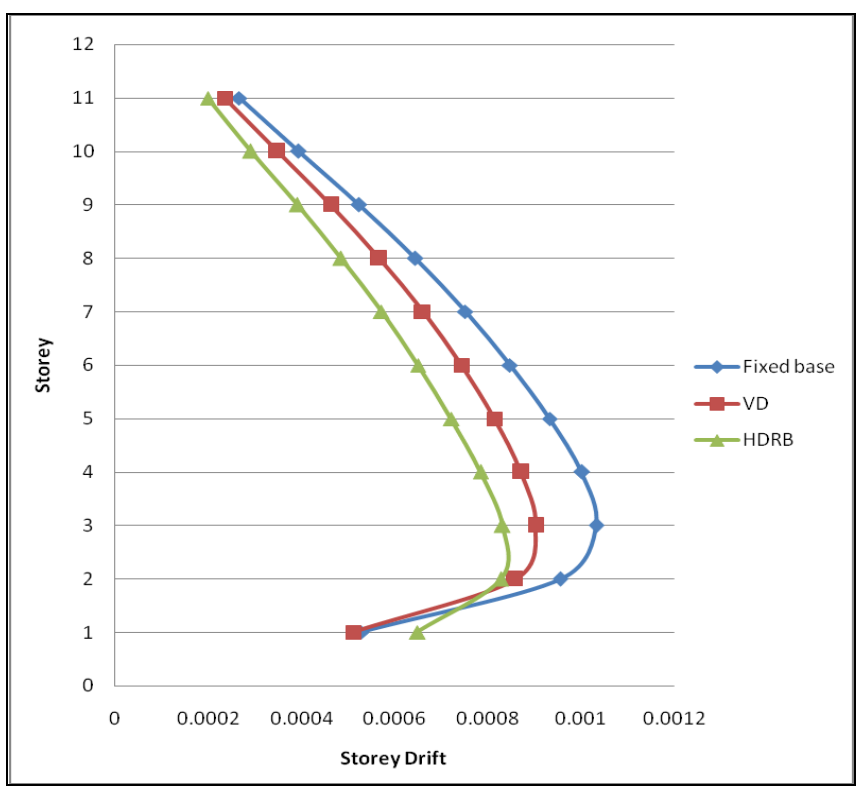

Fig -25: Storey drift of structures for RS analysis in X direction 


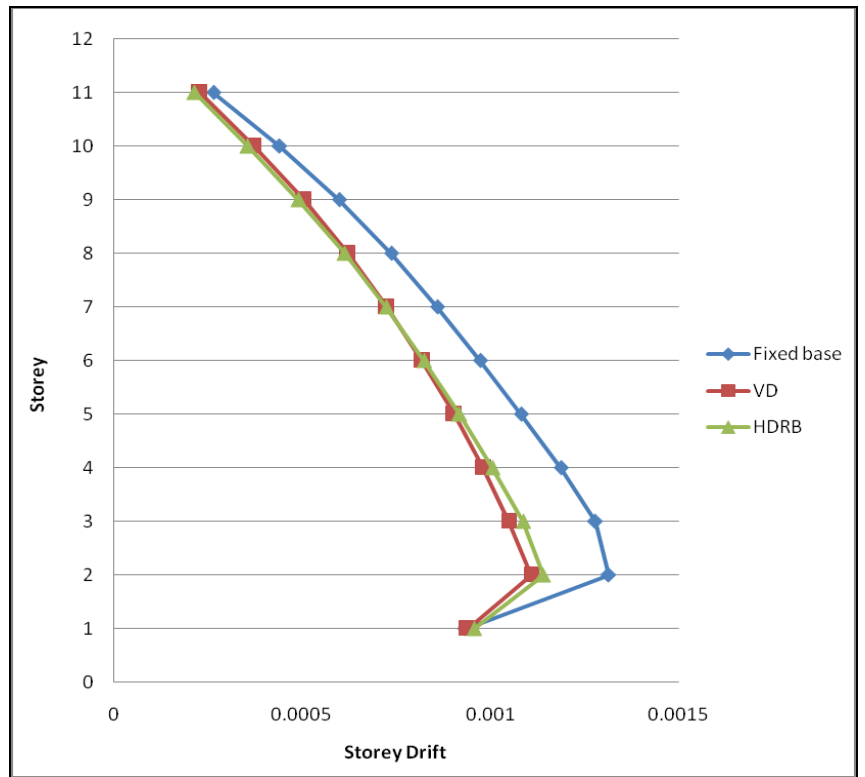

Fig -26: Storey drift of structures for RS analysis in Y direction

\section{CONCLUSIONS}

The result of study shows that response of structures can be reduced by use of high damping rubber bearing isolator and viscous damper.

- In base isolated structure with high damping rubber bearing, storey drift and storey displacement are reduced at greater extent. The variation in maximum displacement of stories in base isolated structure is very low. This is due to the rigid movement of superstructure.

- In structure with viscous damper, storey drift, storey acceleration and storey displacement are reduced at certain extent. Viscous damper have better control effect on displacement.

- In base isolated structure with high damping rubber bearing, storey acceleration is reduced at greater extent. This is due to decrease in lateral loads on the structure.

- High damping rubber bearing isolator lengthens the time period of base isolated structure at greater extent. Viscous damper reduces the time period of structure at certain extent.

- Performance point of both base isolated structure and structure with viscous damper is increased. But performance point of base isolated structure is significantly increased.

- Overall there is significant reduction in values of storey displacement, storey drift, storey acceleration by lengthening the natural period of vibration for base isolated structures. From the above discussion, Seismic performance of base isolates structure is good as compared to structure with viscous damper.

- Base isolation technique has found to be reliable for seismic protection of multi-storey structure.

\section{REFERENCES}

[1]. Trevor E Kelly, Base isolation of structures, Revision 0: July 2001, Holmes Consulting Group Ltd.

[2].Liya Mathew \& C. Prabha, "Effect of fluid viscous dampers in multi-storeyed buildings", International Journal of Research in Engineering \& Technology, ISSN(E) : 2321 8843, ISSN(P) : 2347-4599, Vol.2, Issue 9, Sep 2014, 55-60 [3]. T.K. Datta "Seismic Analysis of Structures", 2010, John Wiley \& Sons (Asia) Pte Ltd.

[4].ATC-40, "Seismic evaluation and retrofit of concrete buildings." Volume 1 and 2 Applied Technology Council, California, 1996

[5]. IS: 1893 (part 1): 2002 Criteria for Earthquake Resistant Design of Structures, BIS, New Delhi, India.

[6].Ashish R. Akhare, Tejas R.Wankhade , "Seismic Performance of RC Structure Using Different Base Isolator", International Journal of Engineering Science \& Research Technology, ISSN : 2277-9655, 3(5) : May 2014

[7].S. M. Dhawade, "Comparative Study for Seismic Performance of Base Isolated \& Fixed Based RC Frame Structure", International Journal of Civil Engineering Research, ISSN 2278-3652 Volume 5, Number 2 (2014), pp.183-190

[8].CSI Analysis Reference Manual for SAP2000

[9].Vardani Bandekar, T.P. Bandivadekar, "Pushover analysis of 15 storey steel building using passive damper system for enhancing seismic performance", 2012-2013

[10].H.P. Santhosh, K.S. Manjunath, K. Sathish Kumar, "Seismic analysis of low to medium rise building for base isolation", International Journal of Research in Engineering and Technology, eISSN : 2319-1163, pISSN : 2321-7308, Nov-2013

[11].FEMA-273."NEHRP guidelines for the seismic rehabilitation of buildings." Federal Emergency Management Agency, Washington DC, 1997

[12].Soong, T.T. "Supplemental energy dissipation: state-ofthe-art and state-of-the-practice", Engineering Structures, 200203

[13].Sang Whan Han. "Evaluation of the seismic performance of a three-story ordinary moment resisting concrete frame", Earthquake Engineering \& Structural Dynamics, 05/2004

[14].Bagheri, Bahador, Salimi Firoozabad, Ehsan and Yahyaei, Mohammadreza, "Comparative Study of the Static and Dynamic Analysis of Multi-Storey Irregular Building”, World Academy of Science, Engineering \& Technology, 2012.

[15].Lin, Yu-Yuan, and Eduardo Miranda. "Estimation of Maximum Roof Displacement Demands in Regular Multistory Buildings", Journal of Engineering Mechanics, 2010.

[16].Providakis, C.P. "Pushover analysis of base-isolated steel-concrete composite structures under near fault excitations", Soil Dynamics and Earthquake Engineering, 


\section{4}

[17].Lin, A. N., and H. W. Shenton. "Seismic Performance of Fixed-Base and Base-Isolated Steel Frames", Journal of Engineering Mechanics, 1992.

[18].Yong, Yuan, Zhu Hongping, and Wei Wei. "Experimental Study of the Dynamic Behavior of HighDamping Rubber-Bearing Isolator", International Efforts in Lifeline Earthquake Engineering, 2013.

\section{BIOGRAPHIES}

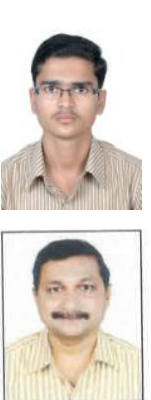

Dhananjay A. Chikhalekar is at final stage of M.Tech at Department of Structural Engineering, Sardar Patel College of Engineering, Mumbai, India.

Dr. M. M. Murudi is a Professor, Vice Principal at Department of Structural Engineering, Sardar Patel College of Engineering, Mumbai, India. 